\title{
Different Strategic Types Operating in the Same Industry: A Multiple Case Study
}

\author{
Gregory Kenneth Laing \\ School of Business, Faculty of Arts \& Business \\ University of the Sunshine Coast, Maroochydore DC, Queensland 4558, Australia
}

Tel: 61-754-594-675 E-mail: glaing@usc.edu.au

Received: December 7, 2012 Accepted: January 9, 2013 Published: June 26, 2013

doi:10.5296/bms.v4i1.2826

URL: http://dx.doi.org/10.5296/bms.v4i1.2826

\begin{abstract}
The purpose of this study is to examine the viability of different strategic types operating in the same industry. The specific industry examined was the general insurance industry in Australia. The Miles \& Snow (1978) strategic typology was used to identify companies that represented the defender, prospector and analyser types. A multiple case study approach was used in order to make comparisons between the companies. Surveys and interviews were conducted to acquire the information. The analysis revealed that different strategic types can successfully exist in the same industry by adopting different performance priorities, different management control systems and different approaches to external environmental issues.
\end{abstract}

Keywords: Australian insurance industry, Strategic planning, Strategic typologies, Multiple case study 


\section{Introduction}

The general insurance industry has a major role in the finance sector and in particular provides security against financial losses for businesses and the general public. The general insurance industry has faced many challenges because of the advent of the global financial crisis as well as major disasters such as floods and storms. Not only is it important to satisfy the shareholders concern for profits it is essential to have sound business practices that provide continued liquidity. Since 1960 some 23 general insurance companies have gone into liquidation in Australia placing greater concern over the approach to strategic planning in the general insurance industry.

Prior studies have identified strategic planning as a process of setting organisational goals and objectives (Rowe, Mason \& Dickel,1985). Strategic planning has also been classified as a process of formulating the direction of an organization by management (Daft \& Macintosh, 1984) requiring the evaluation of the current environment, external and internal, to formulate assumptions about an otherwise uncertain future (Ansoff \& McDonnell, 1990). Fern and Tipgos (1988) described strategic planning as the process of setting out to provide a framework for future directions of an organization not only for dealing with opportunities and problems but also for the most efficient use of available resources. In essence a strategy provides a framework for decision making to ensure that the activities of an organization are matched to the environment in which it operates.

Whilst prior research has addressed various aspects of the Miles and Snow (1978) strategic typology there has been less attention to examining the relationship of strategic typology to companies within a specific industry sector. This is especially relevant for the examination of the contingent relationship between strategy, environment, control and the selection of an appropriate accounting information system. The empirical evidence linking performance differences with strategic typologies in a single industry has not been extensive and the findings have conflicted. Cool and Schendel (1987) examined the US pharmaceutical industry, and found performance differences due to market share but did not observe any differences in profitability between groups. Johnson and Thomas (1988) studied the UK brewing industry and found variations in performance were greater within groups than between groups. Figenbaum and Thomas (1990) examined the US insurance industry and found differences between groups for economic performance measures and market share. Failure to establish a linkage in some studies may be due to the differences in strategy not adequately representing the groups being examined.

\section{Literature Review}

The strategy that an organization adopts may be influenced by the internal environment it will be specifically relative to the external environment (Miles \& Snow, 1978; Snow \& Hrebiniak, 1980). This forms the basic premise upon which the generic strategic classifications of prospector, defender and analyser were proposed by Miles and Snow (1978) and later extended by Snow and Hrebiniak (1980) to include a fourth classification of the reactor. According to Gordon and Narayanan (1984) the external environment will have a strong influence in determining the type of strategy this leads to the concept of there being a 
continuum upon which the external environment may be explained as moving from a stable existence through an intermediary phase of neither stable nor unstable and through to an unstable existence. Gordon and Narayanan (1984) reported that that the defender favoured a stable external environment, the prospector an unstable one and the analyser one which was in between. In addition the research (Miles \& Snow, 1978; Snow \& Hrebiniak, 1980) identified an additional continuum related to adapting or reacting to change. Accordingly, the Analyser was at the extreme end of this continuum relying on the innovation of others while the reactor merely responds to pressure with little or no concern for the innovation of others. The result of these two competing perspectives provides an insight into variations in strategic typologies that may be explained in terms of companies falling with in quadrants without being purely one strategic typology or another. The realization of this Miles and Snow strategic typology matrix is presented in Figure 1.

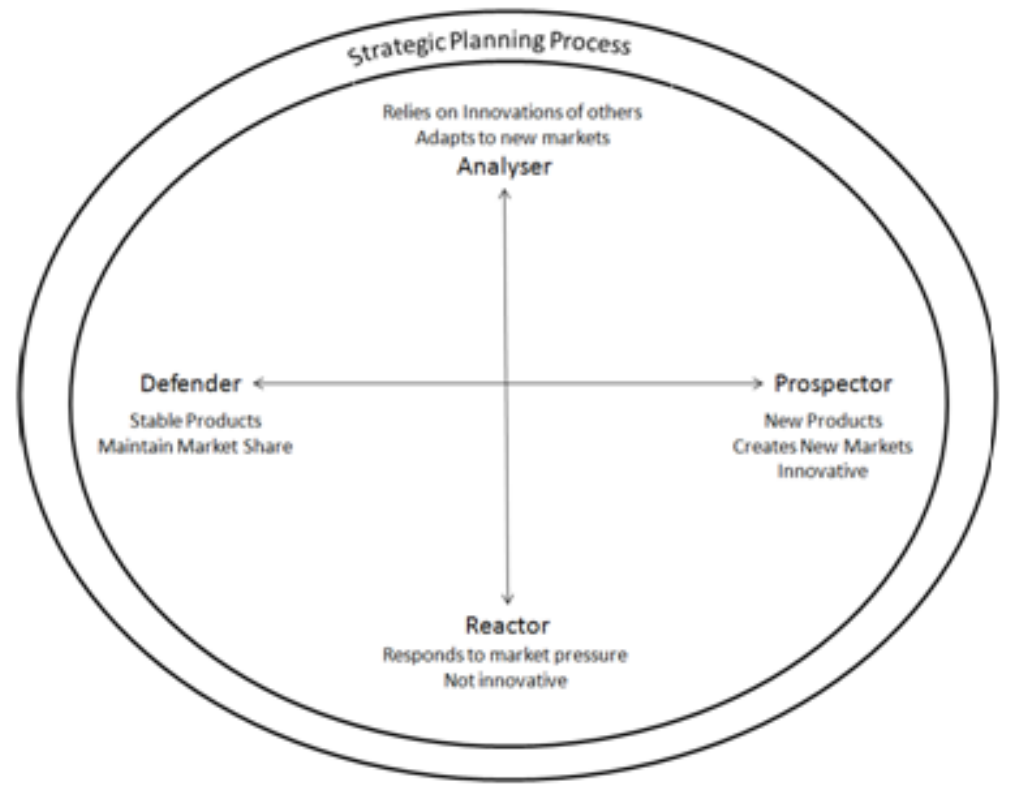

Figure 1. The Miles \& Snow Strategic Typology Matrix

The theoretical model introduced by Khandawalla (1977) proposed a relationship between strategy, organizational environment, management control and organisational performance. In this model the relationships are contingent upon one another and this principle is consistent with contingency model espoused by Cunningham (1992). Contingency theory emphasises the difference in responses to diverse environments and adjustments to the culture and structure within an organization. Cunningham (1992) suggested that when the competitive environment was aligned with an appropriate structure it would influence the choice of control systems leading to different levels of performance.

Prior research (Meyer, 1982; Miller, 1987) identified the relationship between the external environment and the strategy used by companies. Hambrick (1981), Zahara (1987) and Chaganti and Samharaya (1987) highlighted the influence that management had in adoption of a particular strategy where external environments varied. Research by Odom and Boxx (1988) showed how the environment and strategic planning was linked to a company's 
performance. The relationship between strategic types and company performance has been found to exist in a wide aray of settings (Feeser \& Willard, 1990; Figenbaum \& Thomas, 1990; Zajac \& Shortell, 1989; Segev, 1987a; Smith, Guthrie \& Chen, 1986). For a company to be successful in applying a particular strategy it should have an identifiable relationship between its strategic type, external environment, management controls and performance outcomes. The contingent relationship is exemplified in the design of Figure 2.

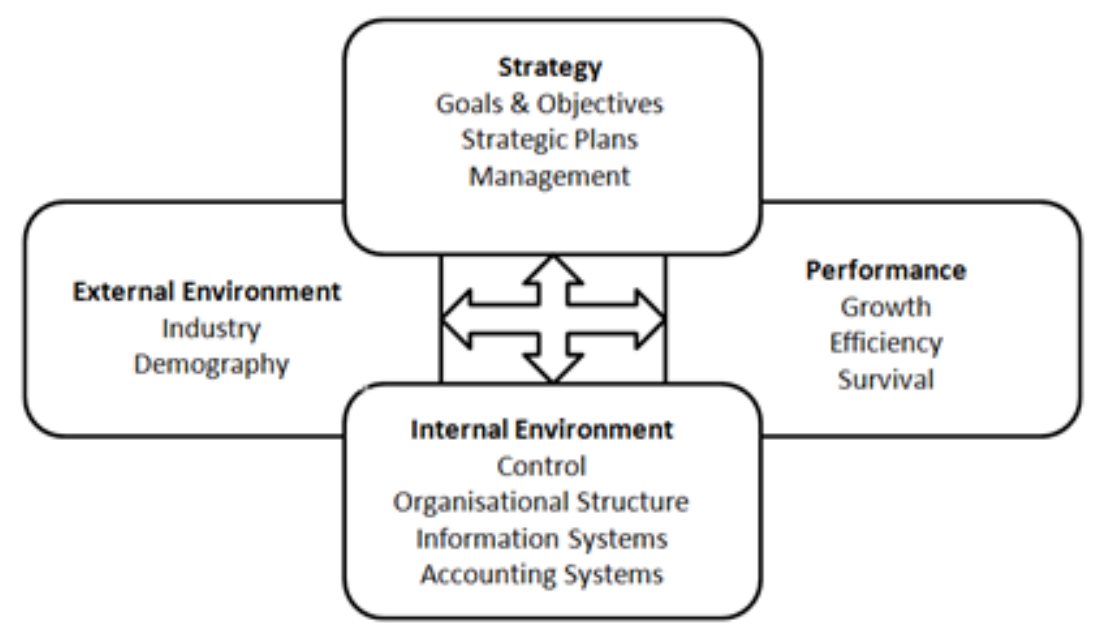

Figure 2. The Contingency Relationship of Strategy, External Environment, Internal Environment and Performance

Research (Simons, 1987; Gordon, Larcker \& Tuggle, 1978) has established a relationship between the strategic plan and the accounting system required to provide an appropriate system for monitoring and control within companies. Bhimani and Bromwich (1989) and Allen (1985) found that the need for information went beyond the mere financial data and extended to information pertaining to competitors and the life cycle of products and resources. Bhimani and Bromwich $(1989,27)$ referred to this as strategic management accounting which provides a link between strategic planning and the operational activities of a company.

\section{Method}

The method used in this paper is a multiple case study which is based on the literature which suggested that a well structured case study has the potential to add knowledge to a specific field of inquiry such as strategic management accounting practices (Yin, 1989; Burgess, 1984; Hagg \& Hedlund, 1979).

Case studies offer the opportunity to validate alternatives particularly industry specific practices (Yin, 1989). The industry specific performance measures add substance to the case study approach. The inclusion of established methods of performance evaluation, in the analysis process, provides enhanced validity for the findings. The data sources for this paper were drawn from general insurance companies operating in Australia. The three companies were the Union Insurance Company Ltd (referred to as Company A) representing the defender, the Fire and All Risks Insurance Company Ltd (referred to as Company B) representing the prospector, and the Royal Insurance Company Ltd (referred to as Company 
C) representing the analyser.

This multiple case study approach therefore consists of three individual cases. Each case is representative of a unique strategic typology as per the classification by Miles and Snow (1978). To identify the typology of the companies the questionnaire developed and tested by Snow and Hambrick (1980) was used. This is a self -typing questionnaire approach which asks the management to select the category which most fits or describes the strategic plan, aims and objectives of their respective company. This lead to the selection of companies that strongly identified with the typologies of defender, analyser and prospector.

Having selected one company from each strategic typology a more expansive questionnaire was then used to acquire details on issues relating to strategy, external environment, internal environment and performance measures. Likert scales were used to distinguish between the participants responses on each of these areas.

In summary, the Miles and Snow (1978) strategic types of prospector, analyser and defender are the classificatory variables. Control variables were the organizational structure (Williams \& Hinings, 1988), delegation of responsibility (Sizer, 1989; Rayburn, 1989; Bierman et al, 1990) and the budgeting process (Brownell, 1982a, 1982b and Collins, Munter \& Finn, 1987, Laing, 2008). External environmental variables as identified by Schermerhorn (1986), Stanton et al (1991) and Sera (1992) were demography, economic conditions, competition, social and cultural forces and legal forces, as well as technological forces. The performance and measurement variables consisted of accounting based indicators (Edwards, 1986), effectiveness and efficiency indicators (Otley, 1978) and return on investment (Schoeffler et al, 1974; Miller, 1988; White, 1986; Venkatraman \& Prescott, 1990).

Data analysis consisted of examining, categorizing and tabulating the information in accordance with pattern matching and explanation-building as recommended by Yin (1989). Pattern matching involved the comparison of findings with the predicted or expected pattern of specific variables as defined by the classificatory variable or strategic type. Lack of precision is a limitation in this method, however the use of multiple cases enhances the use of pattern matching by providing theoretical replication (Yin, 1989). Explanation building is the analysis of the case study data presented in narrative form. Limitations of this method can relate to the complexity and difficulty in measuring issues and narratives may tend to drift away from the issues. To minimise the possible limitations, a chain of evidence approach is recommended to show links with theoretical propositions (Yin, 1989).

\section{Company A - Defender}

The general manager of company A had identified the company as being the defender type which is primarily concerned with maintaining a market niche, providing superior service and a limited but stable range of products. Company A predominantly operated in the rural sector and vigorously sought to maintain its market niche. To that end the strategic plan was developed to cover a three to five year time horizon with top priority being given to quality of products, services and market share. The progress of the operations were reviewed on a monthly basis and management were committed to monitoring activities at the grass root 


\section{Macrothink Institute ${ }^{\text {TM }}$}

level. Particular attention was given to any changes that could signal the entry of a new competitor or a new product in the market. Software had been developed to highlight changes to any key indicators and reports were succinct, presenting numeric and graphical data.

\subsection{Performance Measures}

Company A had a focus on profit derived solely from the individual insurance product categories. Management placed a greater importance on the overall performance and the reporting system allowed for trends in the market to be detected earlier than was previously possible. The importance of formal corporate strategy on the long-term profitability was supported by the responses of the general manager to the performance priorities as per Table 1 .

\subsection{Management Accounting Controls}

Control is achieved through formal budgets, responsibility centres and activity ratios such as underwriting ratios, product turnover, claims loss ratios and average collection period ratios. The general manager ranked 'formal corporate strategy and objectives to guide line managers' as the number one priority. The high priority given to formal control and monitoring of the existing market share is consistent with the defender typology. The priority of the control systems as ranked by the general manager are presented in Table 2.

\subsection{External Environment}

The general manager stated that the general insurance industry was subject to periods of fluctuation due to natural disasters, economic conditions, and changes in the number competitors in the market. To emphasise this company A had provided what was referred to as an insurance clock based on the cycles which had been observed to occur in the general insurance industry. The insurance clock is replicated in Figure 3. The general manager pointed to legislation as the major cause of additional costs. Technology was also a major cost with dramatic changes in the processing of all aspects of the insurance operations. The perception of the major external influences to the company as ranked by the general manager are presented in Table 3. 


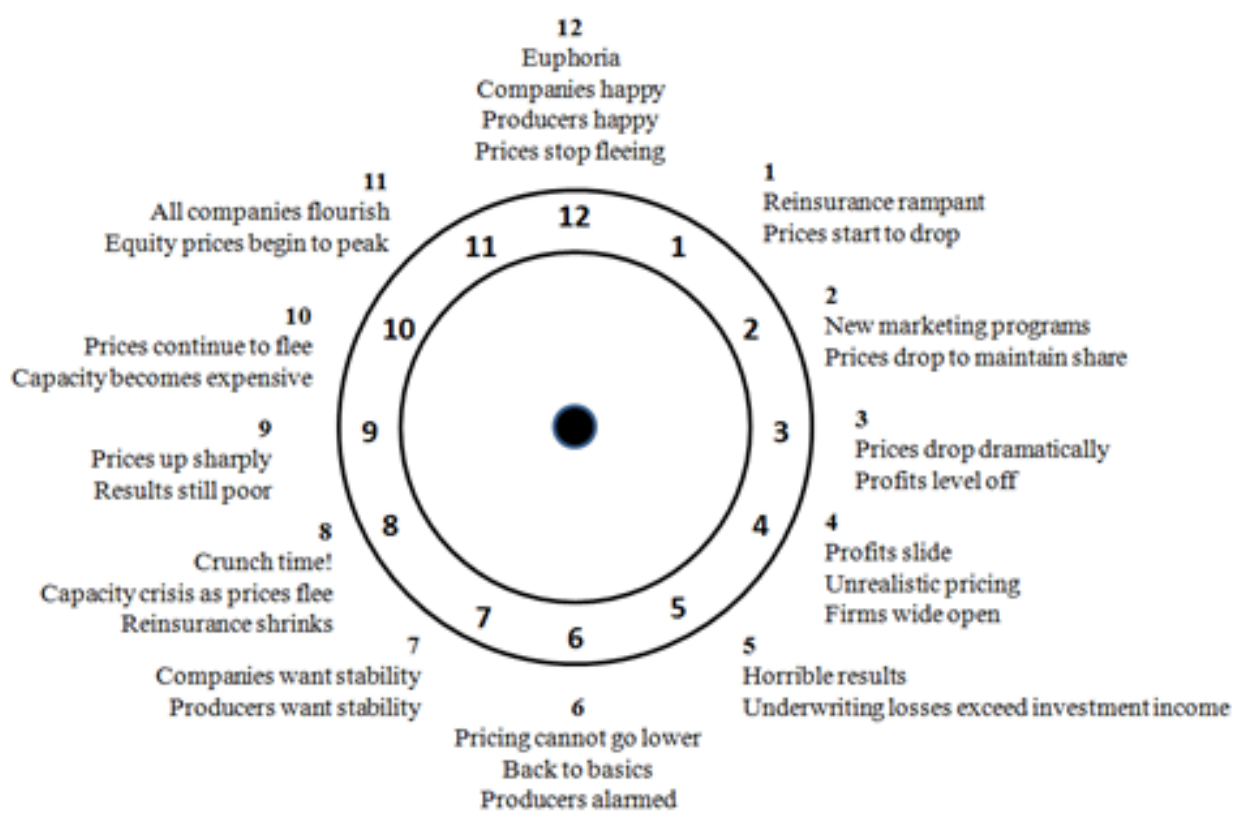

Figure 3. The Insurance Clock

In summary company A was consistent in its focus on maintaining its market niche which was reflected in its approach to performance measurements, management accounting controls and monitoring of the external environment. The strategy is to protect its market niche, control systems are designed to provide feedback on performance concerned with maintaining market share.

\section{Company B - Prospector}

The assistant general manager of company B had identified the company as being the prospector type, which values being first-in with new products and creating new markets or products. Company B operated in a broad product market adopting an aggressive approach to seeking and developing both new products and new markets. The company was not content with operating as just an insurance provider and had diversified by providing reinsurance to other insurance companies as well as diversification into other areas outside the insurance industry.

\subsection{Performance Measures}

Performance was measured on the profitability of products by category and this was considered to be consistent with the priority for an aggressive approach to developing new markets. Managers were encouraged to take risks and act on any new products or markets. Diversification was considered to be a strategic priority for the growth of the company. If a product or market did not live up to expectations then the company would simply move on to the next new product or market. An incentive scheme provide bonuses to all staff for productivity and new ideas. Profits and financial stability were the focus of the performance evaluations and this is reflected in the ranking provided by the assistant general manger to the performance priorities in Table 1. 


\subsection{Management Accounting Controls}

Control focuses on the differences between revenues and all assignable cost. The investments and divisions were evaluated on the income derived from the investment base. Control was achieved through assigning costs attributable or controllable by each income generating centre. Budgets were predominantly concerned with cash flow and profit margins. However, capital budgeting techniques were a formal part of the strategic planning process focusing on research and development. The high priority on market research and research and development is consistent with the prospector strategy type. The priority of the control systems as ranked by the assistant general manager are presented in Table 2.

\subsection{External Environment}

The diversification by company A meant that it faced risks that extended beyond the Australian insurance market. Due to the different types of business it conducted it was subject to government legislation beyond that which applied to the insurance industry in Australia. The assistant general manager claimed that the flexibility of the company meant that it could move from one market to another although there had been some financial problems with diversification activities and there was a priority for the company to recover from the losses it had experienced. The company had been quick to adopt new technology and had invested in the training of staff at all levels in line with its strategic objectives of being at the forefront of new product development and innovation. The problems faced by the company due to excessive diversification and risk taking are evident in the ranking of the major external influences by the assistant general manger presented in Table 3.

In summary company B was consistent with the prospector typology through its focus on new products and new markets in the insurance industry and beyond the geographical limits of Australia. The organizational structure allowed for managers at all levels to respond quickly to any new opportunities and this was very much a part of the reward incentive scheme that applied even to the lower levels of staff. The emphasis on monitoring profitability of products and services and culling any as and when they became unprofitable is still very much consistent with the prospector typology.

\section{Company C - Analyser}

The assistant general manager of company $\mathrm{C}$ had identified the company as being the analyser type, which attempts to maintain a stable line of products and/or services whilst maintaining a state of preparedness to be able to take advantage of new products or markets, preferring to be second-in with a more cost efficient product or service. Company $\mathrm{C}$ operated in a broad product market adopting an aggressive approach to seeking and developing both new products and new markets. The company was not content with operating as just an insurance provider and had diversified by providing reinsurance to other insurance companies as well as diversification into other areas outside the insurance industry. The company had adopted the strategy of aligning with financial institutions to achieve wider market penetration and relied on these financial institutions to recognise new developments in the products and services. The assistant general manager advised that this strategy had allowed 
the company to reduce costs in research and development and more importantly had all but removed the need for advertising.

\subsection{Performance Measures}

Performance was measured on the profitability of products using the traditional method of underwriting income less claims expenses. Analysis of the running costs as related to the various financial intuitions was only done on a quarterly basis. They had entered some new markets and introduced some new products but only after those markets and new products had been in place for over a period of at least one year. The driving force behind the adoption of these new products or markets was the financial institutions. They relied on the research and evaluations presented by the financial institutions rather than worry about investigating issues themselves. The staff training was minimal and what training did take place was focused on meeting existing job skills. There was no incentive scheme for staff because management felt that the financial institutions did the job for less than it had previously cost the company. The symbiotic relationship had proven to be profitable and as indicated by the responses from the assistant general manager profit and financial strength ranked highly as performance priorities in Table 1.

\subsection{Management Accounting Controls}

Control focused on the differences between insurance product revenues and corresponding claims expenses. The goal for the company was to achieve a high growth in its products and this meant monitoring new business levels and retention of existing clients. Subsequently the budgets were aimed at dissecting the insurance products along the lines of new clients and existing clients. All decisions were made by the general manager in consultation with the assistant general manager, effectively there was no autonomy given to any lower level management. This approach is reflected in the priority of the control systems as ranked by the assistant general manager and presented in Table 2.

\subsection{External Environment}

The reliance on the financial institutions had lead company $\mathrm{C}$ to be an early adopter of new technology. This was due to the need to provide the financial institutions with a seamless link and access to the computer records of the company. Again emphasizing the symbiotic nature of the relationship that had grown. When the assistant general manager spoke of customers there was some blurring of the difference between the clients who they insured and the financial institutions that had placed them with the company. So when the assistant general manager spoke of customer needs he indicated that he was referring equally to the financial institutions. This dichotomy is evident in his ranking of the major external influences on the company in Table 3.

In summary the company was suffering from an excessive reliance on other institutions to fulfill its stated strategic goals. The company computer system produced copious amounts of information about so many different aspects of the insurance products and the various financial institutions with all their branches. This combined with the rule that none but the general manager could make a decision had a negative effect on performance. The company 
was not achieving its stated goal of profitability and liquidity but had been suffering a decline in both of these areas. In effect this company may best be described as an analyser that was teetering on the brink of becoming a reactor.

\section{Comparison}

The priorities of performance measures as ranked by the companies, presented in Table 1, does provide some surprises. In particular the ranking of the performance measures by company A, the defender, and company B the prospector are very similar with both selecting the ' Retaining or securing [a high] or [above average] liquidity and financial strength' as their number one priority. This may explain the anomaly of company $\mathrm{B}$, the prospector outperforming company A, the defender. Hambrick (1983) reported that in every type of environment that had been examined the defenders outperformed prospectors across all industries.

Table 1. Performance Priorities

\begin{tabular}{|l|l|l|l|}
\hline Priorities of performance measures & $\begin{array}{l}\text { Rank } \\
\text { by Coy } \\
\text { A }\end{array}$ & $\begin{array}{l}\text { Rank } \\
\text { by Coy } \\
\text { B }\end{array}$ & $\begin{array}{l}\text { Rank } \\
\text { by Coy } \\
\text { C }\end{array}$ \\
\hline Earning [a high] or [above average] profit & 2 & 2 & 1 \\
\hline $\begin{array}{l}\text { Achieving [a high] or [above average] rate of growth in sales } \\
\text { or revenues }\end{array}$ & 3 & 3 & 3 \\
\hline $\begin{array}{l}\text { Retaining or securing [a high] or [above average] liquidity } \\
\text { and financial strength }\end{array}$ & 1 & 1 & 2 \\
\hline $\begin{array}{l}\text { Maintaining or securing [a high]or [above average] employee } \\
\text { morale, job satisfaction, and commitment to firm's objectives }\end{array}$ & 4 & 5 & 4 \\
\hline Achieving or maintaining an excellent public image & 5 & 4 & 5 \\
\hline
\end{tabular}

Performance measures obtained from the financial reports of the companies indicate that company B, the prospector had the best results. The summarized details of the financial performance indicators are presented in Table 2. These ratios suggest that the performance, at least in the companies studied, was linked to the strategic type and the control system applied. Interestingly company B was found to have the most appropriate and successful approach to managing control in line with its strategic type and thus was able to improve performance.

Table 2. Comparison of Performance Measurements

\begin{tabular}{|c|c|c|c|}
\hline $\begin{array}{l}\text { Performance Measurement } \\
\text { Category }\end{array}$ & Defender $\operatorname{Coy} A$ & $\begin{array}{c}\text { Prospector Coy } \\
B\end{array}$ & Analyser Coy C \\
\hline Accounting based Indicators & $\begin{array}{l}\text { CR } 1.08: 1 \\
\text { PMS } 1.16 \% \\
\text { ROSF } 20.48 \%\end{array}$ & $\begin{array}{l}\text { CR } 1.03: 1 \\
\text { PMS } 12.63 \% \\
\text { ROSF } 29.05 \%\end{array}$ & $\begin{array}{l}\text { CR } 0.45: 1 \\
\text { PMS }-16.44 \% \\
\text { ROSF }-17.65 \%\end{array}$ \\
\hline $\begin{array}{lll}\text { Effectiveness } & / & \text { Efficiency } \\
\text { Indicators } & & \end{array}$ & $\begin{array}{l}\text { MS } 2.31 \% \\
\text { EXRATIO } \\
34.3 \%\end{array}$ & $\begin{array}{l}\text { MS } 11.03 \% \\
\text { EXRATIO } \\
22.5 \%\end{array}$ & $\begin{array}{l}\text { MS } 8.61 \% \\
\text { EXRATIO } \\
34.1 \%\end{array}$ \\
\hline
\end{tabular}




\begin{tabular}{|l|l|l|l|}
\hline & TUWEXP & TUWEXP & TUWEXP \\
& $107.04 \%$ & $97.41 \%$ & $111.36 \%$ \\
\hline
\end{tabular}

CR: Current Ratio - PMS: Profit Margin on Sales - MS: Market Share - EXRATIO: Production Expense

TUWEXP: Total Underwriting Expense

The attributes of the management control system were different in each company. This difference tended to be indicative of the strategy type combined with approach to decision making within the company. While the control systems had similar qualities due to the nature of the general insurance industry the focus and use of the data differed along strategy lines. The ranking of control techniques as presented in Table 3 provides confirmation of these differences.

Table 3. Priority of Control Techniques

\begin{tabular}{|l|c|c|c|}
\hline Control Techniques & $\begin{array}{c}\text { Rank } \\
\text { by Coy } \\
\boldsymbol{A}\end{array}$ & $\begin{array}{c}\text { Rank } \\
\text { by Coy } \\
\boldsymbol{B}\end{array}$ & $\begin{array}{c}\text { Rank } \\
\text { by } \boldsymbol{C o y} \\
\boldsymbol{C}\end{array}$ \\
\hline Formalisation of decision making authority & 9 & 6 & 1 \\
\hline Management control and information systems & 3 & 3 & \\
\hline Executive or management training and development & 5 & 8 & 2 \\
\hline $\begin{array}{l}\text { Research and development of new products/services or } \\
\text { processes }\end{array}$ & 7 & 2 & \\
\hline Forecasting sales, customer preferences, technology etc & 4 & 4 & \\
\hline Market research & 2 & 1 & 5 \\
\hline $\begin{array}{l}\text { Formal, system to search and evaluate new opportunities for } \\
\text { acquisitions, markets or investments }\end{array}$ & 6 & 9 & \\
\hline Market diversification & 8 & 10 & \\
\hline Incentive schemes for increasing productivity of staff & 10 & 5 & 4 \\
\hline $\begin{array}{l}\text { Formal corporate strategy and objectives to guide decision } \\
\text { making by managers }\end{array}$ & 1 & 7 & 3 \\
\hline
\end{tabular}

Not surprising external environment issues were viewed slightly differently by each company. What emerged was a relationship between strategy as expressed in the ranking of the major external influences as presented in Table 4. The prospector, company B, took full advantage of changes and developments in new technology to open new markets and create new products. It also diversified and took risks some of which did not have the desired outcomes and consistent with the prospector philosophy it was quick to get out and cut its losses. In contrast, the analyser, company $\mathrm{C}$, was slow to react to changes preferring to wait for the right moment when it had all the information and could provide a product that would give it a large market share and be more profitable. The problem with the analyser was that it was too slow and relied on outside sources to provide the data and analyses which was to its detriment. The defender, company A, was true to its strategic type and feared competition above all else as this threatened its market niche.

Table 4. External Influences 


\begin{tabular}{|l|c|c|c|}
\hline Major External Influences & $\begin{array}{l}\text { Rank } \\
\text { by Coy } \\
\text { Competition }\end{array}$ & $\begin{array}{l}\text { Rank } \\
\text { by Coy } \\
\text { B }\end{array}$ & $\begin{array}{l}\text { Rank } \\
\text { by } \\
\text { Coy }\end{array}$ \\
\hline Technological change & 2 & 4 & 2 \\
\hline Government intervention (policies and regulation) & 4 & 2 & 3 \\
\hline Customer needs & 3 & 5 & 1 \\
\hline Recovery from diversification losses & & 1 & \\
\hline
\end{tabular}

\section{Summary}

The study shows that different strategic types can successfully exist in the same industry and that to do so will develop different performance priorities, different management control systems and view external environmental issues differently. The differences identified as occurring between these three companies is consistent with the Miles and Snow (1978) typology. Matching of the strategy to an appropriate control system with due consideration of external environmental issues appeared to produce the best results in terms of desired performance. It would seem that strategy and control are indeed interdependent and for any strategy to succeed the control system must provide the appropriate information.

Future research may focus on the role the strategy has on the development of the corporate culture and the resulting variations in the design of the control system. Management were also concerned with developing a corporate identity and this aspect warrants further research to determine the correlation with corporate culture.

\section{References}

Allen, D. (1985). Strategic Management Accounting, Management Accounting, March, $25-27$.

Ansoff, H., \& McDonnell, E. (1990). Implanting Strategic Management (2nd end.)., Prentice-Hall: New York.

Bierman, H. Jr., Dyckman, T., \& Hilton, R. (1990). Cost Accounting Concepts and Managerial Applications, PWS-Kent Publishing Compant: Boston.

Bihmani, A., \& Bromwich, M. (1989). Advanced Manufacturing Technology and Strategic Perspectives in Management Accounting, European Accounting News, January, 21-31.

Brownell, P. (1982a). The Role of Accounting Data in Performance Evaluation, Budgetary Participation and Organizational Effectiveness, Journal of Accounting Research, 20(1), 12-27.

Brownell, P. (1982b). A Field Study Examination of Budgetary Participation and Locus of Control, Accounting Review, 57(4), 766-777. http://dx.doi.org/10.2307/2490760

Chaganti, R., \& Sambharaya, R. (1987). Strategic Orientation and Upper Echelon Characteristics, Strategic Management Journal, 8, 393-401. http://dx.doi.org/10.1002/smj.4250080409 
Collins, F., Munter, P., \& Finn, D. (1987). The Budgeting Games People Play, Accounting Review, 62(1), 29-49.

Cool, K., \& Schendel, D. (1987). Strategic Group Formation and Performance: The Case of the U.S. Pharmaceutical Industry 1963-82, Management Science, 33, 1102-1124. http://dx.doi.org/10.1287/mnsc.33.9.1102

Cunningham, G. (1992). Management Control and Accounting Systems Under a Competitive Strategy, Accounting, Auditing \& Accountability Journal, 5(2), 85-102. http://dx.doi.org/10.1108/09513579210011880

Daft, R., \& Macintosh, N. (1984). The Nature of Formal Control Systems for Management Control and Strategy Implementation., Journal of Management, 10(1), 43-66. http://dx.doi.org/10.1177/014920638401000105

Edwards, J. (1986). The Use of Performance Measures, National Association of Accountants: Montvale.

Fern, R., \& Tipgos, M. (1988). Controllers as Business Strategists: A Progress Report, Management Accounting, March, 25-29.

Fesser, H., \& Willard, G. (1990). Founding Strategy and Performance: A Comparison of High Tech and Low Growth Firms, Strategic Management Journal, 11, 87-98. http://dx.doi.org/10.1002/smj.4250110202

Figenbaum, A., \& Thomas, H. (1990). Strategic Groups and Performance: The U.S. Insurance Industry 1970-84, Strategic Management Journal, 11, 197-215. http://dx.doi.org/10.1002/smj.4250110303

Gordon, L., \& Narayanan, V. (1984). Management Accounting Systems, Perceived Environmental Uncertainty and Organizational Structure: An Empirical Investigation, $\begin{array}{llll}\text { Accounting, } \quad \text { Organizations } & \text { and } & \text { 33-47. }\end{array}$ http://dx.doi.org/10.1016/0361-3682(84)90028-X

Gordon, L., Larcker, D., \& Tuggle, F. (1978). Strategic Design Processes and the Design of Accounting Information Systems: Conceptual Linkages, Accounting, Organizations and Society, 3(3/4), 203-213. http://dx.doi.org/10.1016/0361-3682(78)90012-0

Hagg, I., \& Hedlund, G. (1979). 'Case Studies' in Accounting Research, Accounting, Organizations and Society, 4(1/2), 135-143. http://dx.doi.org/10.1016/0361-3682(79)90013-8

Hambrick, D. (1981). Environmet, Strategy and Power within Top Management Teams, Administrative Science Quarterly, 26, 253-276. http://dx.doi.org/10.2307/2392472

Johnson, G., \& Thomas, H. (1987). Strategic Groups and Financial Perfromance: A Critical Examination, Working Paper, Manchester Business School U.K.

Khandwalla, P. (1977). The Design of Organizations, Harcourt Brace Jovanovich: New York. Laing, G. (2008). Budgeting Games: An Analysis of Budgetary Participation in Statutory 
Authorities, Journal of Economic \& Social Policy, 12(2), 93-116.

Meyer, A. (1982). Adapting to Environmental Jolts, Administrative Science Quarterly, 25, 317-336.

Miles, R., \& Snow, C. (1978). Organizational Strategy, Structure and Process, McGraw-Hill: New York.

Odom, R., \& Boxx, W. (1988). Environment, Planning Processes and Organizational Performance of Churches, Strategic Management Journal, 9, 197-205. http://dx.doi.org/10.1002/smj.4250090209

Otley, D. (1978). Budget Use and Managerial Performance, Journal of Accounting Research, 16(1), 122-149. http://dx.doi.org/10.2307/2490414

Rayburn, (1989). Principles of Cost Accounting Using A Cost Management Approach 4th Edn., Irwin: Homewood.

Rowe, A., Mason, R., \& Dickel, K. (1985). Strategic Management \& Business Policy: A Methodological Approac (2nd Ed.), Addison-Wesley: Reading, Massachusetts.

Schermerhorn, J. Jr., (1986). Management of Productivity (2nd Ed.). John Willey \& Sons: New York.

Schoeffler, S., Buzzell, R., \& Heany, D. (1974). Impact of Strategic Planning on Profit Performance, Harvard Business Review, March/April, 137-145.

Segev, E. (1987). Strategy, Strategy Making and Performance: An Empirical Investigation, Management Science, 33, 258-269. http://dx.doi.org/10.1287/mnsc.33.2.258

Sera, K. (1992). Corporate Globalization: A New Trend, Academy of Management Executive, 6, 89-96.

Simons, R. (1987). Accounting Controls Systems and Business Strategy: An Empirical Analysis, Accounting, Organizations and Society, 12(4) 357-374. http://dx.doi.org/10.1016/0361-3682(87)90024-9

Sizer, J. (1989). An Insight into Management Accounting (3nd Ed.), Penguin Books: Harmondsworth.

Smith, K., Guthrie, J., \& Chen, M. (1989). Strategy, Size and Performance, Organizational Studies, 10(1), 63-81. http://dx.doi.org/10.1177/017084068901000104

Snow, C., \& Hambrick, D. (1980). Measuring Organisational Strategies: Some Theoretical Methodological Problems, Academy of Management Review, 5(4), 527-538. http://dx.doi.org/10.2307/2392457

Snow, C., \& Hrebiniak, L. (1980). Strategy, Distinctive Competence, and Organizational Performance, Administrative Science Quarterly, 25, 317-336.

Stanton, W., Miller, K. \& Layton, R. (1991). Fundamentals of Marketing 2nd Australian 


\section{Macrothink}

Ediition, McGraw-Hill Publishing Co.: Sydney.

Venkatraman, N., \& Prescott, J. (1990). Environment-Strategy Coaglignment: An Empirical Test of Its Performance Implications, Strategic Management Journal, 11, 1-23. http://dx.doi.org/10.1002/smj.4250110102

White, R. (1986). Generic Business Strategies, Organizational Context and Performance: An Empirical Investigation, Strategic Management Journal, 7, 217-231. http://dx.doi.org/10.1002/smj.4250070304

Williams, J., \& Higgins, C. (1988). A Note on Matching Control System Implications with Organizational Characteristics: ZBB and MBO Revisited, Accounting, Organizations and Society, 13(2), 191-198. http://dx.doi.org/10.1016/0361-3682(88)90043-8

Yin, R. (1989). Case Study Research Design and Methods, Sage Publications: Beverly Hills.

Zahra, S. (1987). Corporate Strategic Types, Environmental Perceptions, Managerial Philosophies and Goals: An Empirical Study, Akron Business and Economic Review, 18, 64-77.

Zajac, E., \& Shortell, S. (1989). Changing Generic Strategies: Likelihood Direction and Performance Implications, Strategic Management Journal, 10, 413-430. http://dx.doi.org/10.1002/smj.4250100503 